\title{
Integrating Soft Skills Through Active Learning In The Management Classroom
}

Chynette Nealy, (E-mail: nealyc@uhd.edu), University of Houston-Downtown

\begin{abstract}
This article discusses how active learning can be used to develop soft skills required by managers of contemporary organizations. Findings from course materials developed in response to business and industry demand for increased focus on soft skills are examined using an emerging population, first generation college students in institutions of higher education.
\end{abstract}

\section{INTRODUCTION}

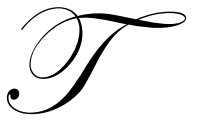

he ability to utilize interpersonal skills are essential in the workplace. Interpersonal skills, often referred to as soft skills, include communication, listening, team problem solving, cross-cultural relations and customer service (Dubrin, 2004). Several studies have been conducted to provide credence for the importance of interpersonal skills needed in business and industry (Murnane, 1996, Maes, Weldy \& Icenogel, 1997; Argenti, \& Forman, 1998; Cameron \& Whetten, 2002,http://www.mba.com, http://www.westga.edu/ bquest). From these studies, soft skills emerged as the top skill business and industry look for in job candidates. For example, data from a survey conducted by the National Association of Colleges and Employers, the Job Outlook 2000, ranked verbal communication [4.61], teamwork [4.61] and interpersonal [4.54] as the top three soft skills required.

These finding can also be used to support feedback from business and industry, which continue to suggest dissatisfaction with the lack of academic preparedness by some recent graduates and/or employees (http://www.pathfinder-one.com, Mackenzie, 2004, Alsop, 2004, http://www.economist.com). This assessment provide management instructors with data that can be used to modify the curricula and teaching techniques considered necessary to prepare future business leader with skills necessary for the 21 st century workplace. An important stakeholder to consider while incorporating this data into programs and/or courses of study is the population being served, students and/or future business leaders. Especially, if the stakeholder has prior experiences and/or currently employed in business and industry. The voice of the customer is a source of knowledge concerning performance of the production and service system (Foster, 2001).

\section{PURPOSE OF THE STUDY}

The study's purpose was to examine active learning as it relates to the development of soft skills to assess its significance to management instructors teaching non-traditional and/or first generation college students. The second purpose was to provide active learning strategies that could be adapted for classroom use in management courses.

\section{RELATED LITERATURE}

There are many factors driving change in today's undergraduate business classrooms. According to Mishel $\&$ Bernstein (1994), one factor, our transformed workforce, is directly linked to these changes. Their findings were supported by the increase of non-traditional college students enrolled in institutions of higher education. Data from the Department of Education indicate that nearly half of the enrolled college student in the United States are twenty- 
four or older. Over one-third are at least thirty-five (Aslanian, 1996, Sargent, 2000). This paper defines nontraditional, as a first generation college student who is the first in his/her families to attend a postsecondary institution (Hicks, 2000). Other characteristics include having dropped out of school, recent immigrants, members of working class families, married, retirees or adults enrolling in school to get the degree they always wanted (Terenzini, Springer, Yaeger, Pascarella, \& Nora, 1996).

The demands to lessen the skills gap by increasing the $21^{\text {st }}$ century workforce with employees that possess skills for a global, competitive and technological workplace (http://www.labor.gov, http://hr.unlv.edu/Diversity/Articles) requires that those teaching and preparing current and future business leaders transform their methods. A subsequent challenge to management instructors involves adapting instruction to accommodate the changing populations of college students in order to provide students with skills that meet business and industry demands.

In response, management instructors should consider changing traditional instructions models and adapting learning models that focuses an integrated approaches with more student involvement (Fink, 1999, Black, 2002). A longitudinal study found that first-generation students are more likely than their non-first-generation peers to have weaker cognitive skills, to underestimate the time needed to study, and, if economic factors dictate, to work more hours off campus (Terenzini, Springer, Yaeger, Pascarella, \& Nora, 1996). It is interesting to note that faculty members may decline the challenge to relinquish traditional learning models because they often teach in environments different from their own educational background, one in which underrepresented populations such as first generations college students may have been overlooked (Allen, 2000).

It seems logical to suggest that because the $21^{\text {st }}$ century workforce and classroom demographics have changed, faculty members preparing future business leaders must undergo a transformation. Emerging from these changes, course materials should consist of a variety of learning activities so that first generation students can join the academic culture and enrich the lives of other students while sharing their experiences with faculty as well (Allen, 2000). Instructors that have had to adjust to the audience of mature students discovered improvements in their teaching and their classes were more dynamic. Mature students tend to be more focused than traditional students in applying their learning, and more motivated to complete their education; they serve as excellent role models. Their life experiences enrich classroom discussions and force both students and instructors to test theory against reality in a variety of disciplines, from ethics to business administration. Mature college students can have a favorable effect both on traditional students and on the quality of instruction (Giezkowski, 1992). These findings and others have relevance to management instructors, specifically in regard to standards for accreditation. The Association to Advance Collegiate Schools of Business (AACSB) Management Education Task Force identified a need for business programs to blur the boundaries between educational disciplines and offer innovative programs. Business programs are encouraged to use effective pedagogies and to include action learning and technology (AACSB, 2002). This reasoning is supported by previous literature that asserts a variety of instructional strategies should be used to develop and achieve different learning objectives and attainable learner's outcomes.

\section{ADVANTAGES OF ACTIVE LEARNING}

Weber (2002) reported that researchers Ford, Peter; Goodyear, Peter; Heseltine, Richard; Lewis, Roger; Darby, Jonathon, Graves, Joyce, Satorius, Harwood, Dave and King, Tom, in Managing Change in Higher Education (Open University Press, 1996), and Christopher Lucas in Crisis in the Academy: Rethinking Higher Education in America (MacMillan Press, 1996) support curriculum changes that will improve more students' learning opportunities at college and university (http://www.newhorizons.org/strategies/mi/weber3.htm). Mirroring this pedagogical shift, active learning is recommended to educators as a means to promote a wider and general knowledge base and interpersonal skills such as communication, problem solving and team work (Bean, 1996, Sutherland \& Bonwell, 1996, Silberman, 1996). Active learning is a simulation or game approach which has four distinctive features: (1) a search for meaning and understanding, (2) a focus on student responsibility, (3) a concern with skills as wells as knowledge, and (4) an approach to the curriculum which leads beyond graduation to a wider career and social setting (Lucas, 1997). Students today are consumer-oriented and demand convenience for their busy schedules. They enroll and/or decide to return to college late because of: career advancement, job or career 
change, increased earning potential, increase confidence, personal enjoyment and meeting people with similar interest (Dover, 2001).

Interactions of students in team activities enrich the experiences of all students by engaging them in the sharing of personal perspectives. Active learning experiences can benefit traditional and non-traditional students who have different backgrounds and cultures. Mature students often have life experiences related to work, family and cultural changes that younger students may never have considered. Additionally, diverse students with differing background can add cross-national information an essential skills needed for management of different employees (Cooper \& Robinson, 1998).

\section{METHODOLOGY}

The subjects involved in this study were 20 first generation college students. They were among sixty students (traditional and non-traditional) enrolled in two management classes at a large urban university. The students who were identified as first generation included 13 females and 7 males students. Eight of the students or 40 percent were African Americans and 12 or 60 percent were Hispanic. The ages of the subjects ranged from 25 to 45 years. The data revealed that 70 percent of this team included an age range of 25-35 years. The data also revealed that 5 or 25 percent of the team were unemployed, 9 were employed part-time and 6 were employed fulltime.

Participants had a traditional lecture-discussion focusing on the development of soft skills required to function in a variety of settings and to assume leadership positions. Next, students had individual assessed exercises which involved examining the topic of soft skills challenges in today's businesses in greater detail. The third phase involved specific applications which included mixing theory with practical applications required in the workplace. During this phase students were divided into teams and assigned a case study involving one of three management simulations, (1) communication and technology, (2) human relation and (3) records and information management.

In the area of communication and technology, the teams were expected to analyze problems in the simulation involving the evaluation of job applications, resumes, and notices or announcements sent to employees. They were expected to perform this task in a virtual office approach to identify and correct oral and written communications. The team was expected to build trust in a virtual environment that could be used during the traditional meeting. This meeting would consist of a face-to-face- mock interview in order for the teams to experience a current approach (virtual then traditional interview) being used by several businesses to interview potential employees.

The objective of this simulation allowed participants to develop communication skills and build trust within a virtual environment. The expected outcomes of this experience were to increase participants' level of comfort before personal contact and enhance team communication skills. Development of these soft skills relate to business in that they promote understanding of customer responsiveness. In this information age, many businesses are using technological advances to assist customers prior to a traditional meeting. Businesses are also using technology to conduct interviews of potential employees from various locations to lessen travel expenses.

In the area of human relations, team members were expected to analyze problems in the simulation involving barriers associated with limited cultural awareness and age discrimination. The team was instructed to develop short scenarios in which members would role- play identified workforce challenges. Team members are made aware they are expected to fully explain and justify solution to the problems.

The objective of this simulation allowed participants to develop skills required to work with others in a global workforce. This activity also promoted development of listening skills required to understanding cultural differences. The expected outcomes of this experience were to enhance participants' understanding that the $21^{\text {st }}$ century workforce will continue with an increase of more women, numerous minorities, older workers and other issues all of which bring new challenges. Participants have the ability to translate learning experiences into practical 
application in order to lessen perceived barriers associated with cultural communications and other employee differences.

In the area of records and information management, the teams were expected to analyze ethical challenges faced by a records manager. The team develops a professional code of ethics mirroring corporation commitment to social awareness and accountability. Team members were also instructed to identify companies recognized as good corporate citizens.

The objective of this simulation allowed participants to enhance and/or develop ethical awareness needed to effectively utilize soft skills. Current events in corporate news strongly support the need for participants to clearly articulate ideas, utilize critical thinking skills and establish work ethics reflective of accountability. The expected outcomes were to assist participants' understanding of ethical decision-making strategies to avoid ethical dilemmas.

At the end of the six weeks period allotted for this assignment, the teams completed a collaborated formal written research report. They also prepared and delivered a collaborative oral presentation. During the six weeks period, teams members were encouraged to meet at least twice outside the academic setting to discuss the project. This supplemental activity was included because related literature suggested First Generation College students were less socially integrated that traditional students, less likely to go places with academic peers, and less likely to participate in study groups (Nunez \& Cuccaro-Almin, 1998).

\section{ANALYSIS OF DATA}

In each of the 6 teams which constituted both of traditional and non-traditional students, the oral and written summaries revealed that a large majority were encouraged with their understanding of theory and practical applications experienced. The overall common themes from summaries revealed students: demonstrated knowledge and application of soft skills needed by management to positively influence organizational behavior, apply rational decision making approaches, develop a collaborative work plan and work in teams.

Although all the teams completed a list of benefits or characteristics they gained from the active learning experienced, this paper focuses the first generation college students' results. These findings supports active learning research, specifically Lucas (1997) assertions of: (1) a search for meaning and understanding, (2) a focus on student responsibility, (3) a concern with skills as wells as knowledge, and (4) an approach to the curriculum which leads beyond graduation to a wider career and social setting. Table I represents the findings from identified respondents.

Table 1 Perceptions of First Generation College Students Outcomes Related to the Active Learning Project

A gain in self -confidence

Improved oral and written communication skills

A greater willingness to accept ideas of others

Greater respect from traditional students

A gain of credibility due to actual work experience

Younger students accepted mature views due to life experiences

A gain of knowledge and understanding of other cultures

Learned the negative aspects of stereotypes

Learned that active learning activities can be informative and fun

Made friends with some team members who had been less active in class

Overcame some shyness

Learned more about technology and various applications

Learned to disagree without feeling angry

Gain confidence that goals can be achieved with assistance (instructor and peers)

Recognized the importance of organization and employees relationships 


\section{SUMMARY}

This study proposed to identify the effects of active learning activities on first generation college student enrolled in two management courses. The study was prompted as a result of identified characteristics and/or problems associated with First Generation College students noted in related literature. Consequently, the instructor was compelled to broadened her knowledge about students being served and how to provide activities, which foster their success in meeting challenges of today's businesses needs.

The active learning activities provided first generation College students an opportunity to develop soft skills and other skills needed for productive performance in the $21^{\text {st }}$ century workplace. Students examined theory and made practical applications within a simulated environment depicting organizational complexity. This process encouraged and allowed first generation college students to adapt, personalize and discover their own method for understanding course material. It provided a unique and enriching shared exchange of individual and team awareness. The pedagogical benefits of active learning are supported by the positive responses from first generations college students.

\section{IMPLICATIONS} businesses:

The outcomes of the study bring awareness to active learning that should be addressed by academia and

1. Continued study into the effectiveness of active learning as it related to first generation college students is needed.

2. Management instructors should explore opportunities to integrate active learning into course activities using the voice of the customer.

3. Collaborative teams consisting of academicians and practitioners are needed to identify soft and other skills needed for employment.

4. Flatten organizational structures and an emerging population (first generation) in institutions of higher education requires those preparing future business leaders to rethinking traditional teaching strategies and update curriculum.

Further research should increase the number of first generation college students perhaps in a survey conducted to determine their perceived effectiveness of active learning with regards to problems identified in related literature. The study offers a way management instructors may begin to rethink the approach to improving soft skills. Although the study focused on one population and approach, it can be used to continue emphasis on the need for development of soft skills needed by current and future business leaders.

\section{REFERENCES}

1. AACSB International - the Association to Advance Collegiate Schools and business. Biz Schools at Risk. (2002, May-June, Retrieved August 4, 2004 from the World Wide Web at http: //www. aacsb.edu/publications/... /may-june02/p48-55 Biz Schools at Risk.pdf.

2. Allen, M. (2000). "Teaching non-traditional students". American Psychological Society Observer, 13 (7), 16-23.

3. Alsop, R. (2004). Top Schools Struggle To Teach Soft Skills. Retrieved August 14, 2004 from the World Wide Web at http://www.careerjournal.com/specialreports/bschool03/

4. Argenti, Paul A. \& Forman, J. (1998). "Should business schools teach Aristotle?" Strategy \& Business. Retrieved August 14, 2004 from the World Wide Web at http://www.strategy-business.com/briefs/98312

5. Aslanian, C. (1996). "Students over twenty-Four Becoming the Norm at U.S. Colleges." College Board News May-June, 1.

6. Bean, J. C. (1996). The professor's guide to integrating writing, critical thinking, and active learning in the classroom. San Francisco: Jossey-Bass Publishers.

7. Business School Graduates “Well Prepared For Work” http://www.pathfinder-one.com 
8. Cameron, K. \& Whetten, D. (2002). Developing management skills. Upper Saddle River: Pearson Prentice Hall.

9. Cooper, J., \& Robinson, P. (1998). Small-group instruction in science, mathematics, engineering and technology (SMET) disciplines: A status report and an agenda for the future. Retrieved August 21, 2004 from the World Wide Web at http://www.wcer.wisc.edu/nise/cl1/CL/resource/ smallgrp.htm.

10. Dover, K. (2001, September 27). Adult Learner Stories - Successful nontraditional Students. Retrieved August 14, 2004 from the World Wide Web at http://www. http://adulted.about.com/od/studentprofiles/

11. Dubrin, A. (2004). Human Relations: Interpersonal, Job-Oriented Skills, Eighth Edition. Pearson Prentice Hall.

12. Foster,T. (2001). The Voice of the Customer. Managing Quality An Integrative Approach Upper Saddle River: Prentice Hall. P. 127-128.

13. Giezkowski, W. (1992). "The Influx of Older Students Can recitalize Teaching." Chronicle of Higher Education: B3B4. LeBreton, Gil.Letter to Herman Crow.

14. Hicks, T. (2002, December 16). "Advising the first-generation college student: Effective retention tools for colleges and universities". The Mentor: An Academic Advising Journal, 5(1). Retrieved March 3, 2003, from http://www.psu.edu/dus/mentor/.

15. Job Outlook 2000, National Association of Colleges and Employers, http://www.naceweb.org/FormsLogin.asp?/pubs/JobOutlook/joboutlook2000/report.html.

16. Lucas, T. (1997). Promoting Secondary School Transitions for Immigrant Adolescents. ERIC Digest. Retrieved March 3, 2003, from http://www.ericdigests.org/1997-3/promoting.html

17. Maes, J, Weldy,T. \& Icenogel, M. (1997). "A Managerial Perspective: Oral Communication is Most Important for Business Students in the Workplace". The Journal of Business Communication. 34.1 67-80.

18. Mackenzie, M. (2004). Management Education: Identifying The Skill Set that Employers Require. Retrieved September 14, 2004, from http://www.apps.aomonline.org/InteractivePapers/pdf/2004/10596.pdf

19. Mishel, L. \& Bernstein, J. (1994). The State of Working America: 1945-95, Economic Policy Institute New York: M.E. Sharp. page 142.

20. Murnane, R. (1996). Teaching the new basic skills: Principles for educating children to thrive in a changing economy. New York: Free Press.

21. Nunez, A.\& Cuccaro-Alamin, S. (1998). First-generation students: Undergraduates whose parent never enrolled in postsecondary education (NCES 1999-082). U.S. Department of Education, NCES. Washington, DC: U.S. Government Printing Office.

22. Sargent, C. (2000). Traditional Degrees for Nontraditional Students. Farrar, Straus \& Giroux. Secretary of Labor Elaine Chao Speech www.labor.gov/_sec/media/speeches

23. Silberman, M. (1996). Active Learning: 101 Strategies to Teach any Subject. Allyn and Bacon: Needham Heights, MA.

24. Steven, B. (2004) How Satisfied Are Employers With Graduates' Business Communication Skills? A survey of Silicon Valley Employers. Retrieved September 14, 2004, from http://www. westga.edu/ bquest.

25. Sutherland, T. \& Bonwell, C. (1996). Using Active Learning in College Classes A Range of Options for Faculty. Jossey-Bass Publisher.

26. Terenzini, P, Springer, L., Yaeger, P. Pascarella, E. \& Nora, A. (1996). First-generation college students: Characteristics, experiences, and cognitive development. Research in Higher Education, 37(1), 1-22.

27. The Changing Nature of work in the $21^{\text {st }}$ Century: Implications for Hispanics http://hr.unlv.edu/Diversity/Articles The MBA - some history http://www.economist.com.

28. Weber, E. (2002). Five-Phases To PBL: MITA (Multiple Intelligence Teaching Approach) Model For Redesigned Higher Education Classes. Retrieved September 14, 2004, from http://www.newhorizons.org/strategies/mi/weber3.htm.

29. What Recruiters What Corporate Recruiters Say http://www.mba.com/mba/AssessCareersTheMBA/htm. 